\title{
Effect of peat samples drying on measured content of carbon and nitrogen fractions
}

\begin{abstract}
The aim of the study was to compare the content of carbon and nitrogen fractions in fresh and dried samples of peat. The samples were extracted in $0.25 \mathrm{~mol} \mathrm{KCl} \cdot \mathrm{dm}^{-3}, 0.25 \mathrm{~mol} \mathrm{H}_{2} \mathrm{SO}_{4} \cdot \mathrm{dm}^{-3}$ and $2.5 \mathrm{~mol} \mathrm{H}_{2} \mathrm{SO}_{4} \cdot \mathrm{dm}^{-3}$. Based on the extractions and analysis of total organic carbon (TOC) and total nitrogen (TN) following fractions of carbon and nitrogen were isolated: nonhydrolyzable carbon (NHC) and nitrogen (NHN), hardly hydrolyzable carbon (HHC) and nitrogen (HHN), easy hydrolyzable carbon (EHC) and nitrogen $(\mathrm{EHN})$, dissolved organic nitrogen $(\mathrm{DON})$, and its ammonium $\left(\mathrm{NH}_{4}-\mathrm{N}\right)$ and nitrate $\left(\mathrm{NO}_{3}-\mathrm{N}\right)$ form. Large differences between fresh and dried samples were observed in the content of some analyzed fractions - especially $\mathrm{NO}_{3}-\mathrm{N}, \mathrm{NH}_{4}-\mathrm{N}$, DON and HHC. 1.6-3.5 times higher concentrations of $\mathrm{NO}_{3}-\mathrm{N}$ were observed in dry samples in comparison with fresh. In dried samples were also observed higher concentrations of $\mathrm{NH}_{4}-\mathrm{N}$ and DON. In general lower concentrations of EHN, NHN, HHC and higher of HHN and EHC were observed in dried samples in comparison to fresh. Higher content of mineral nitrogen, as well as DON and DOC in dried samples, is probably an effect of mineralization of carbon and nitrogen compounds during initial stage of drying. The obtained data suggest, that the content of $\mathrm{NO}_{3}-\mathrm{N}, \mathrm{NH}_{4}-\mathrm{N}, \mathrm{DON}$ and $\mathrm{EHC}$ analyzed in dried samples of peat is overestimated. Extractions of the fractions from organic samples should be done based on fresh samples, just after sampling.
\end{abstract}

Key words: Histosols, carbon fractions nitrogen fractions, soil extraction

\section{INTRODUCTION}

It is well known, that sampling methods of soils and procedures of their preparation for analysis can strongly affect the results. The standard procedure of soil preparation prior to chemical analysis is drying at room temperature or in an oven at temperature usually not exceeding $40^{\circ} \mathrm{C}$. Chemical analyses (including extractions of different components of soil) are usually carried out based on air-dried material within even a few months after sampling. Meanwhile, during the drying and storing the samples changes in their chemical and physical properties can take place. The changes in chemical composition, leading to increase or decrease of particular components concentration, are usually an effect of accelerated activity of microorganisms, which can be positively stimulated by temperature in initial stage of drying. Changes in physical properties of samples can influence efficiency of extraction. Particularly large changes take place during drying samples which are rich in organic matter (e.g. peat, which change the structure and become hydrophobic properties). Finally, measured values of the content of some components in extracts of fresh and dry samples can significantly differ each other (Anderson and Beverly 1985; Gil- liam and Richter 1988; Shepherd et al. 2007; Száková et al. 2010). The aim of the study was to assess of the influence of peat samples drying on the concentrations of carbon and nitrogen fractions.

\section{MATERIAL AND METHODS}

Ten samples of peat were collected in June 2013 from headwater peatlands in the valley of Kamienna Creek (northern Poland). Degree of peat mass decomposition in the field was determined after von Post scale (Grosse-Brauckmann 1990). Roots and parts of wood over $1 \mathrm{~cm}$ large were removed from the samples in sampling day. Then, the samples were mixed and divided into two parts. The same day first part was extracted three times - in $0.25 \mathrm{~mol} \mathrm{KCl} \cdot \mathrm{dm}^{-3}$ ( 3 hours in room temperature), $0.25 \mathrm{~mol} \mathrm{H}_{2} \mathrm{SO}_{4} \cdot \mathrm{dm}^{-3}$ (3 hours in $\left.90^{\circ} \mathrm{C}\right)$ and $2.5 \mathrm{~mol} \mathrm{H}_{2} \mathrm{SO}_{4} \cdot \mathrm{dm}^{-3}\left(3\right.$ hours in $\left.90^{\circ} \mathrm{C}\right)$ (Kalembasa 1995, Becher and Kalembasa 2011). In $0.25 \mathrm{~mol} \mathrm{KCl} \cdot \mathrm{dm}^{-3}$ extracts were analyzed: the content of nitrate nitrogen $\left(\mathrm{NO}_{3}-\mathrm{N}\right)$ by colorimetric method with sodium salicylate, ammonium nitrogen $\left(\mathrm{NH}_{4}-\mathrm{N}\right)$ by steam distillation using distilling unit VELP UDK-127 and dissolved organic nitrogen (DON) with Kjeldahl method. The content of carbon in $0.25 \mathrm{~mol} \mathrm{H}_{2} \mathrm{SO}_{4} \cdot \mathrm{dm}^{-3}$ and $2.5 \mathrm{~mol} \mathrm{H}_{2} \mathrm{SO}_{4} \cdot \mathrm{dm}^{-3}$ 
extracts was analyzed using Tiurin method. The content of nitrogen in the same extracts was determined by Kjeldahl method. Remaining after extraction soil samples were quantitatively moved to evaporating dishes, dried in $105^{\circ} \mathrm{C}$ until the constant weight, and weighted.

The second part of peat sample was dried in $40^{\circ} \mathrm{C}$ until the constant weight and crushed to the size of aggregates less than $1 \mathrm{~cm}$. After two weeks samples were extracted and analyzed using the same methods as for fresh samples. A part of samples was milled and analyzed for the content of soil organic matter (SOM) as loss on ignition in $550^{\circ} \mathrm{C}, \mathrm{pH}$ with potentiometer method, content of total organic carbon (TOC) with Alten method and total nitrogen (TN) with Kjeldahl method.

Based on the extractions, in fresh and dried samples the content of following fractions of carbon and nitrogen was calculated:

- easy hydrolyzable carbon $(\mathrm{EHC})=$ the content of organic carbon extracted using $0,25 \mathrm{~mol}$ $\mathrm{H}_{2} \mathrm{SO}_{4} \cdot \mathrm{dm}^{-3}$,

- hardly hydrolyzable carbon $(\mathrm{HHC})=$ the content of organic carbon extracted using $2,5 \mathrm{~mol}$ $\mathrm{H}_{2} \mathrm{SO}_{4} \cdot \mathrm{dm}^{-3}-\mathrm{EHC}$

- nonhydrolyzable carbon $(\mathrm{NHC})=$ TOC $-\mathrm{EHC}-$ HHC,

- nitrate nitrogen $\left(\mathrm{NO}_{3}-\mathrm{N}\right)=$ the content of $\mathrm{NO}_{3}-\mathrm{N}$ extracted using $0,25 \mathrm{~mol} \mathrm{KCl} \cdot \mathrm{dm}^{-3}$,

- ammonium nitrogen $\left(\mathrm{NH}_{4}-\mathrm{N}\right)=$ the content of $\mathrm{NH}_{4}-\mathrm{N}$ extracted using $0,25 \mathrm{~mol} \mathrm{KCl} \cdot \mathrm{dm}^{-3}$,

- dissolved organic nitrogen $(\mathrm{DON})=$ the content of Kjeldahl's nitrogen extracted using 0,25 $\mathrm{mol} \mathrm{KCl} \cdot \mathrm{dm}^{-3}-\mathrm{NH}_{4} \mathrm{~N}$,

- easy hydrolyzable nitrogen $(\mathrm{EHN})=$ the content of nitrogen extracted using $0,25 \mathrm{~mol}$ $\mathrm{H}_{2} \mathrm{SO}_{4} \cdot \mathrm{dm}^{-3}-\mathrm{DON}-\mathrm{NH}_{4} \mathrm{~N}$,

- hardly hydrolyzable nitrogen $(\mathrm{HHN})=$ the content of nitrogen extracted using $2,5 \mathrm{~mol}$ $\mathrm{H}_{2} \mathrm{SO}_{4} \cdot \mathrm{dm}^{-3}-\mathrm{EHN}-\mathrm{DON}-\mathrm{NH}_{4} \mathrm{~N}$,

- nonhydrolyzable nitrogen $(\mathrm{NHN})=\mathrm{TN}-\mathrm{HHN}-$ EHN-DON- $\mathrm{NH}_{4}-\mathrm{N}$.

Statistica software was applied to statistical analysis.

\section{RESULTS AND DISCUSSION}

Carbon and nitrogen, as major components of soil organic matter are present in the soils in different forms, which can be extracted with suitable reagents (Kelley and Stevenson 1995; Shulten and Shnitzer 1998). One of the commonly used method is sequential extraction in $0.25 \mathrm{~mol} \mathrm{KCl} \cdot \mathrm{dm}^{-3}, 0.25 \mathrm{~mol}$ $\mathrm{H}_{2} \mathrm{SO}_{4} \cdot \mathrm{dm}^{-3}$ and $2.5 \mathrm{~mol} \mathrm{H}_{2} \mathrm{SO}_{4} \cdot \mathrm{dm}^{-3}$, which allows to isolate a few fractions of carbon and nitrogen of different susceptibility to acid hydrolyzis and mineral fractions of nitrogen (Kalembasa 1995; Kalembasa and Becher 2009; Becher and Kalembasa 2011). The method is applied both to mineral and organic samples, which are usually extracted as air-dried in different time after sampling. However, results of many studies show, that measured values of concentration of some components in fresh and dried samples can significantly differ each other (Anderson and Beverly 1985; Gilliam and Richter 1988; Shepherd et al. 2007; Száková et al. 2010). It is a result of microbiological processes running during drying and storing of samples, and changes in physical properties of samples, which can influence efficiency of extraction. The investigated samples were characterized by high degree of peat mass decomposition (7-10 in 10-point scale) and had different content of $\operatorname{SOM}\left(228.4-819.4 \mathrm{~g} \cdot \mathrm{kg}^{-1}\right)$, TOC $\left(121.3-406.9 \mathrm{~g} \cdot \mathrm{kg}^{-1}\right)$, and TN (7.1-28.1 $\left.\mathrm{g}^{\mathrm{kg}} \mathrm{k}^{-1}\right)$ (Table 1). NHC was the major component of TOC with contribution of $65.4-89.0 \%$ in fresh samples and 69.8-86.8\% in dried ones (Fig. 1). The observed differences between fresh and dried samples in the content of NHC and contribution of the form in TOC were small. In all cases, slightly higher concentrations of EHC were observed in dried samples. The differences were the greater, the more SOM and TOC was present in the samples, which is confirmed by high, statistically significant correlation coefficients (Table 2). The content of EHC was also strongly negatively related to peat mass decomposition degree. It can be assumed, that in a few first hours of drying (until the samples contained sufficient amount of water), in relatively low temperature $\left(40^{\circ}\right)$ the biological activity could occur, which resulted in intensive mineralization of carbon and nitrogen compounds. HHC fraction had been mineralized mainly, hence its lower content in dried samples (Fig. 1).

TABLE 1. Selected properties of soil samples

\begin{tabular}{lrlllll}
\hline $\begin{array}{l}\text { Sample } \\
\text { number }\end{array}$ & $\mathrm{H}$ & $\mathrm{pH}_{\mathrm{H} 2 \mathrm{O}}$ & $\begin{array}{l}\mathrm{SOM} \\
{\left[\mathrm{g} \cdot \mathrm{kg}^{-1}\right]}\end{array}$ & $\begin{array}{l}\text { TOC } \\
{\left[\mathrm{g} \cdot \mathrm{kg}^{-1}\right]}\end{array}$ & $\begin{array}{l}\mathrm{TN} \\
{\left[\mathrm{g} \cdot \mathrm{kg}^{-1}\right]}\end{array}$ & TOC:TN \\
\hline 1 & 7 & 6.15 & 819.4 & 406.9 & 26.0 & 15.7 \\
2 & 9 & 6.23 & 467.2 & 257.7 & 18.4 & 14.0 \\
3 & 9 & 6.04 & 294.3 & 134.6 & 10.3 & 13.0 \\
4 & 9 & 6.04 & 804.2 & 384.4 & 26.4 & 14.6 \\
5 & 10 & 5.77 & 462.0 & 251.4 & 17.0 & 14.8 \\
6 & 9 & 5.80 & 241.8 & 121.3 & 10.2 & 11.8 \\
7 & 10 & 6.45 & 766.7 & 388.1 & 28.1 & 13.8 \\
8 & 9 & 6.04 & 494.8 & 269.8 & 15.7 & 17.2 \\
9 & 9 & 6.33 & 228.4 & 132.5 & 7.1 & 18.6 \\
10 & 10 & 6.25 & 311.0 & 219.4 & 13.4 & 16.4 \\
\hline
\end{tabular}

Explanations: $\mathrm{H}$ - degree of peat mass decomposition after von Post scale; SOM - soil organic matter; TOC - total organic carbon; $\mathrm{TN}$ - total nitrogen. 
TABLE 2. Statistically significant (at $p<0.05$ ) correlation coefficients between the differences in the content of carbon and nitrogen fractions measured in fresh and dried samples vs the content of SOM, TOC, TN and H

\begin{tabular}{llllllllll}
\hline & $\mathrm{EHC}$ & $\mathrm{HHC}$ & $\mathrm{NHC}$ & $\mathrm{NO}_{3}-\mathrm{N}$ & $\mathrm{NH}_{4}-\mathrm{N}$ & $\mathrm{DON}$ & $\mathrm{EHN}$ & $\mathrm{HHN}$ & $\mathrm{NHN}$ \\
\hline SOM & 0.675 & - & - & 0.666 & - & - & - & - & - \\
TOC & 0.681 & - & - & 0.633 & - & - & - & - & - \\
TN & - & - & - & 0.729 & - & - & - & - & - \\
$\mathrm{H}$ & -0.758 & - & - & - & - & - & -0.778 & - & - \\
\hline
\end{tabular}

Explanations: $\mathrm{H}$ - degree of peat mass decomposition after von Post scale; $\mathrm{SOM}$ - soil organic matter; TOC - total organic carbon; TN - total nitrogen;

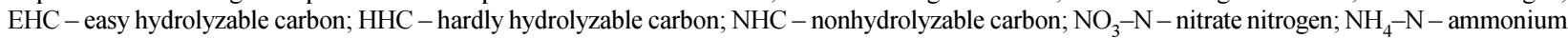
nitrogen; DON - dissolved organic nitrogen; EHN - easy hydrolyzable nitrogen; HHN - hardly hydrolyzable nitrogen; NHN - nonhydrolyzable nitrogen.

content $\left[\mathrm{g}^{\mathrm{kg}} \mathrm{k}^{-1}\right]$
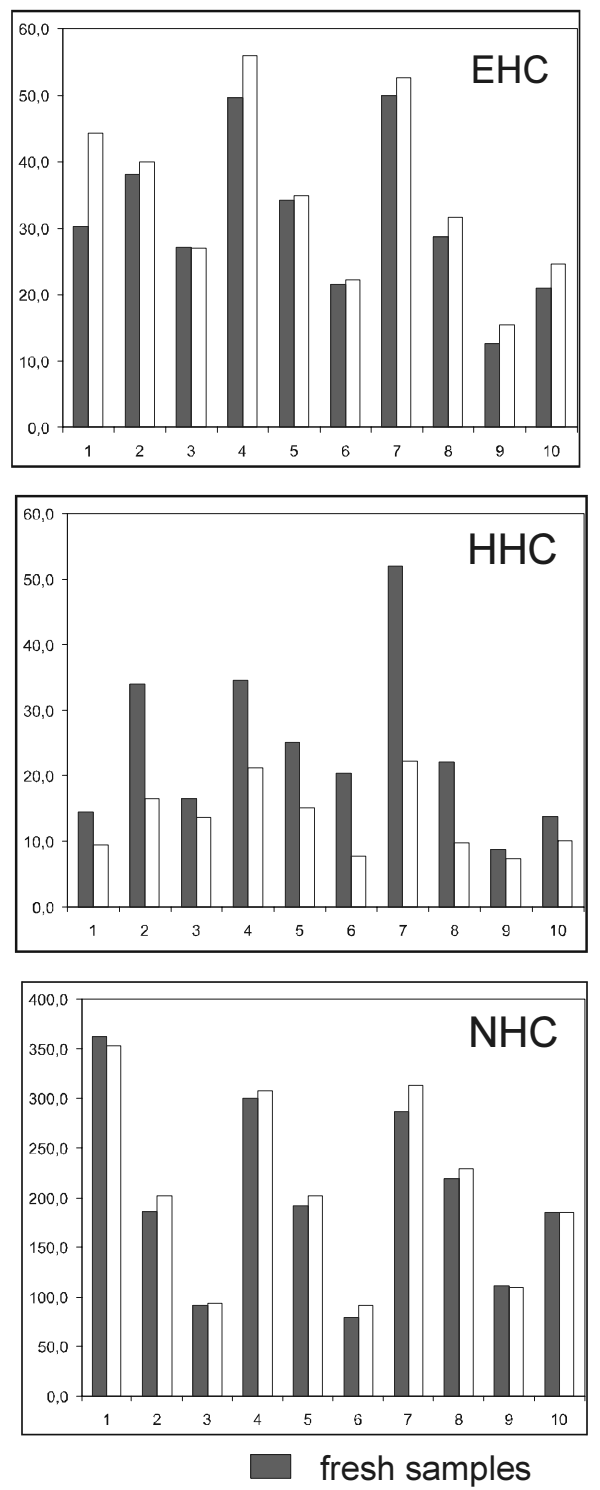

contribution in TOC [\%]
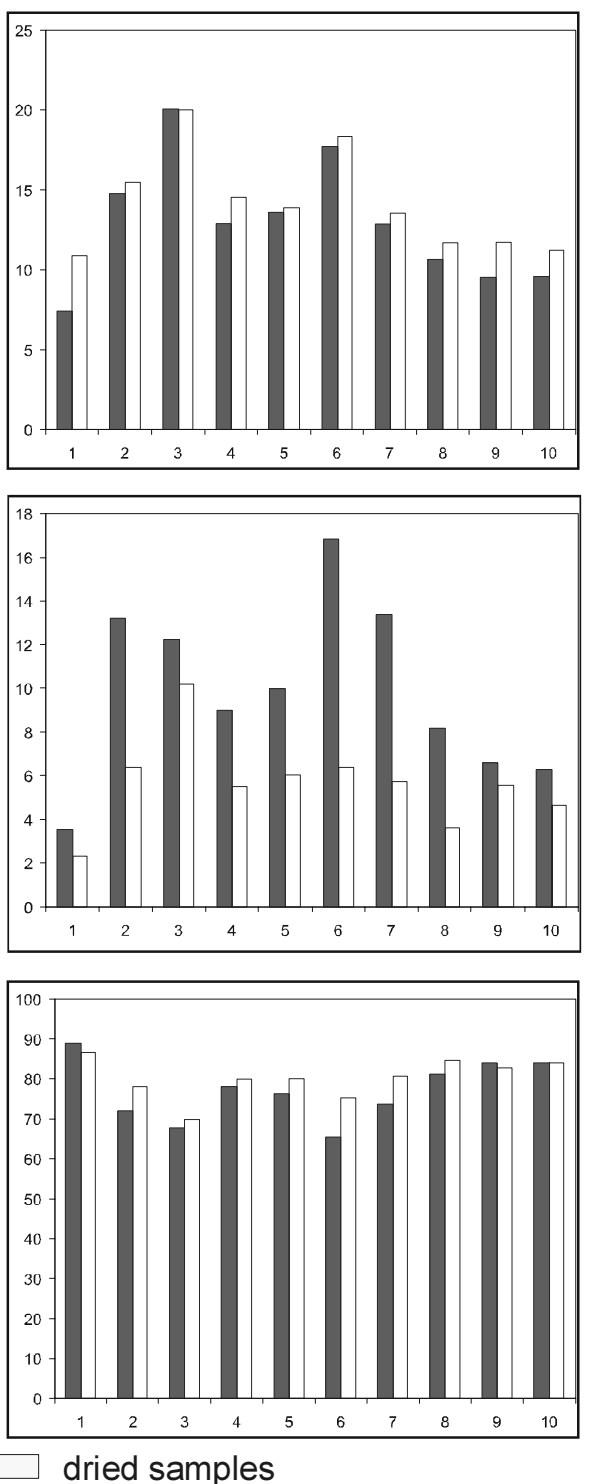

FIGURE 1. The content of carbon fractions and their contribution in TOC measured in fresh and dried samples

Mineral nitrogen is usually not very abundant constituent in soil (Kalembasa and Becher 2009), which is mainly a result of intensive uptake by plant roots and microorganisms. $\mathrm{NH}_{4}-\mathrm{N}$ form usually dominate in the pool. Such regularities were also noticed in the investigated samples, however large differences in the content both nitrate and ammonium form measured in fresh and dried samples (Fig. 2) were observed. The content of $\mathrm{NO}_{3}-\mathrm{N}$ ranged from 0.0000032 to $0.0000264 \mathrm{~g} \cdot \mathrm{kg}^{-1}$ in fresh samples, and from 0.0000072 to $0.0000497 \mathrm{~g} \cdot \mathrm{kg}^{-1}$ (1.6-3.5 times higher) in dried ones. The size of difference between fresh and dried samples in the content of $\mathrm{NO}_{3}-\mathrm{N}$ was strongly positively correlated with the content of SOM, 
content $\left[\mathrm{g} \cdot \mathrm{kg}^{-1}\right]$
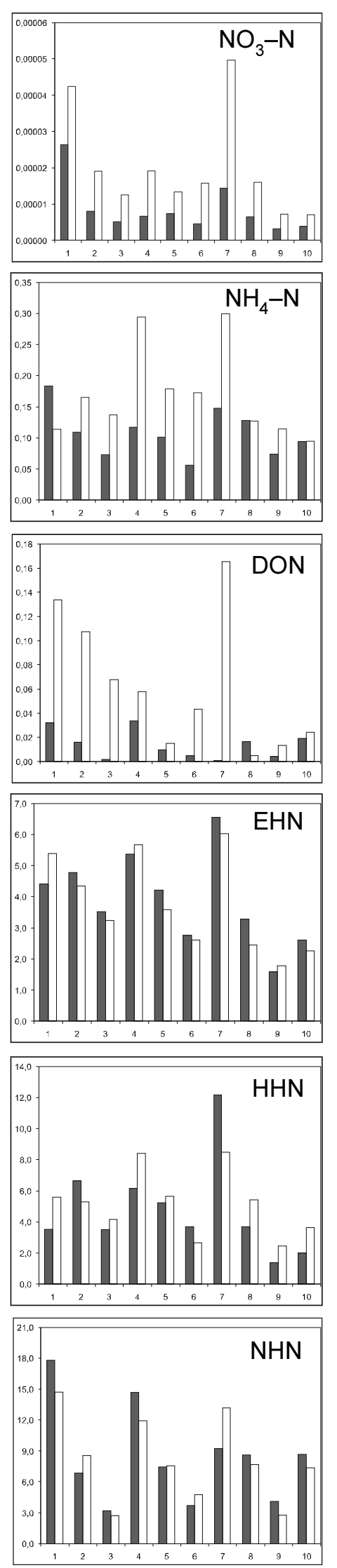

fresh samples contribution in TOC [\%]
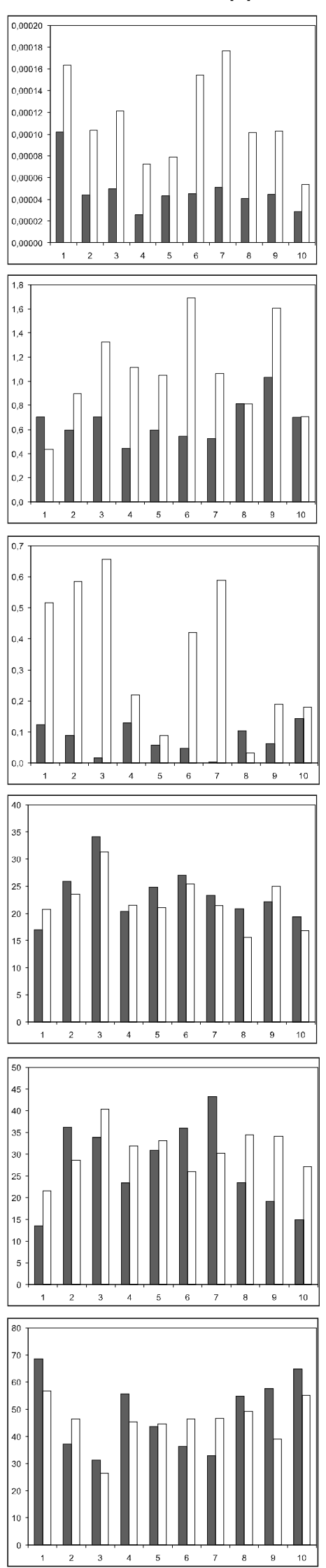

dried samples
TOC and TN (Table 2). The measured content of $\mathrm{NH}_{4}-\mathrm{N}$ in most cases was also higher

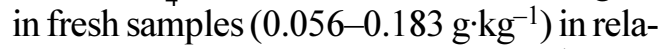
tion to dried ones $\left(0.095-0.300 \mathrm{~g}^{-1} \mathrm{~kg}^{-1}\right)$. The highest differences between fresh and dried samples were observed in the content of DON (Fig. 2), however concentrations of this form were relatively low $(0.0007-$ $0.0339 \mathrm{~g} \cdot \mathrm{kg}^{-1}$ in fresh samples and 0.0050 $0.1652 \mathrm{~g} \cdot \mathrm{kg}^{-1}$ in dried ones). Drying of peat samples had also some effect on measured content of EHN, HHN and NHN, but it was not so clear as for $\mathrm{NO}_{3}-\mathrm{N}, \mathrm{NH}_{4}-\mathrm{N}$ and DON.

\section{CONCLUSIONS}

1. The data obtained clearly show an effect of drying of peat samples on measured values of some carbon and nitrogen fractions - particularly $\mathrm{NO}_{3}-\mathrm{N}, \mathrm{NH}_{4}-\mathrm{N}$ and DON. Higher concentrations of the components were observed in dried samples in compare to fresh. The differences were the greater, the more SOM and TN were present in the samples, which was confirmed by statistically significant correlation coefficients. Differences in the content of EHC, HHN and NHN were not so high and clear. Higher content of HHC was observed in fresh samples. Higher content of EHC was found in dried samples than in fresh ones.

2. The increase of the concentration of $\mathrm{NO}_{3}-\mathrm{N}, \mathrm{NH}_{4}-\mathrm{N}$, as well as DON and EHC, after drying, is probably an effect of increased microbiological activity in soil samples during the first stages of drying, and intensive mineralization of organic carbon and nitrogen. The concentration of the fractions determined in dried samples are overestimated. Results of the experiment suggest, that extractions of carbon and nitrogen fractions from organic samples should be done based on fresh samples, just after sampling.

FIGURE 2. The content of nitrogen fractions and their contribution in TN measured in fresh and dried samples 


\section{REFERENCES}

Anderson D.L., Beverly R.B., 1985. The effects of drying upon extractable phosphorus, potassium and bulk density of organic and mineral soils of the everglades. Soil Science Society of America Journal, 49: 362-366.

Becher M., Kalembasa D., 2011. Fractions of nitrogen and carbon in humus horizons of arable Luvisols and Cambisols located on Siedlce upland. Acta Agrophysica, 18(1): 7-16. (In Polish).

Gilliam F.S., Richter D.D., 1988. Correlations between extractable $\mathrm{Na}, \mathrm{K}, \mathrm{Mg}, \mathrm{Ca}, \mathrm{P} \& \mathrm{~N}$ from fresh and dried samples of two Aquults. Journal of Soil Science, 39: 209-214.

Grosse-Brauckmann G., 1990. Ablagerungen der Moore [In:] Moor- und Torfkunde (Göttlich K., ed.). E. Schweizerbart'sche Verlagsbuchhandlung: 175-236.

Kalembasa S., 1995. Zastosowanie izotopów ${ }^{15} \mathrm{~N}$ i ${ }^{13} \mathrm{~N}$ w badaniach gleboznawczych i chemiczno-rolniczych. WNT, Warszawa: $252 \mathrm{~s}$.
Kalembasa D., Becher M., 2009. Fractions of nitrogen in drained peat-muck soils located in the upper Liwiec River valley. Water-Environment-Rural Areas, 9(2): 73-82. (In Polish).

Kelley K.R., Stevenson J.F., 1995. Forms and nature of organic $\mathrm{N}$ in soil. Fertilizer Research, 42: 1-11.

Shepherd M., Bhogala A., Barrett G., Dyera C., 2007. Dissolved organic nitrogen in agricultural soils: effect of sample preparation on measured values. Communications in Soil Science and Plant Analysis, 32(9-10): 1523-1542.

Shulten H.R., Shnitzer M., 1998. The chemistry of soil organic nitrogen: a review. Biology and Fertility of Soils, 26: 1-15.

Száková J., Miholová D., Tlustoš P., Šestáková I., Frková Z., 2010. Effect of soil properties and sample preparation on extractable and soluble $\mathrm{Pb}$ and $\mathrm{Cd}$ fractions in soils. Agricultural Sciences, 1(3): 119-130.

Received: September 6, 2013

Accepted: January 8, 2014

\section{Wpływ procesu suszenia próbek gleb torfowych na zawartość frakcji węgla i azotu}

Streszczenie: Celem badań była ocena wpływu procesu suszenia próbek gleb torfowych na zawartość frakcji węgla i azotu. Ekstrakcje prowadzono w ujednoliconych próbkach świeżych (w dniu poboru) oraz tych samych próbkach po ich wysuszeniu w temperaturze $40^{\circ} \mathrm{C}$ i przechowywaniu przez okres dwóch tygodni. Na podstawie ekstrakcji gleb w $0,25 \mathrm{~mol} \mathrm{KCl} \cdot \mathrm{dm}^{-3}, 0,25 \mathrm{~mol}$ $\mathrm{H}_{2} \mathrm{SO}_{4} \cdot \mathrm{dm}^{-3}$ i $2,5 \mathrm{~mol} \mathrm{H} \mathrm{SO}_{4} \cdot \mathrm{dm}^{-3}$ oraz analizy zawartości węgla organicznego (TOC) i azotu całkowitego (TN) wydzielono następujące formy węgla i azotu: węgiel niehydrolizujący (NHC), azot niehydrolizujący (NHN), trudno hydrolizujący węgiel (HHC) i azot $(\mathrm{HHN})$, łatwo hydrolizujący węgiel $(\mathrm{EHC}) \mathrm{i}$ azot $(\mathrm{EHN})$, rozpuszczalny azot organiczny $(\mathrm{DON})$ oraz forma amonowa $\left(\mathrm{NH}_{4}-\mathrm{N}\right)$ i azotanowa $\left(\mathrm{NO}_{3}-\mathrm{N}\right)$ tego pierwiastka. Obserwowano duże różnice pomiędzy próbkami świeżymi i suszonymi pod względem zawartości niektórych form węgla i azotu, szczególnie $\mathrm{NO}_{3}-\mathrm{N}, \mathrm{NH}_{4}-\mathrm{N}$, DON and HHC. W próbkach suszonych notowano 1,6-3,5 razy większe stężenia $\mathrm{NO}_{3}-\mathrm{N}$, a także znacznie większe stężenia $\mathrm{NH}_{4}-\mathrm{N}$ i DON. Na ogół niższe stężenia EHN, NHN, HHC i wyższe HHN i EHC występowały w próbkach suszonych w porównaniu do świeżych. Wyraźnie wyższa zawartość: azotu mineralnego, DON i DOC w próbkach suszonych, jest zapewne efektem zwiększonej mineralizacji związków węgla i azotu w początkowej fazie suszenia. Uzyskane dane wskazuja, że zawartość $\mathrm{NO}_{3}-\mathrm{N}, \mathrm{NH}_{4}-\mathrm{N}$, DON i EHC oznaczona w próbkach organicznych po ich suszeniu jest zawyżona. Ekstrakcje tych frakcji powinny być wykonywane w próbkach świeżych, w dniu ich poboru.

Słowa kluczowe: gleby organiczne, formy węgla, formy azotu, ekstrakcja gleb 